\title{
Students' Environmental Literacy Understanding in Science Learning: A Preliminary Study
}

\author{
Muchtar Haryanto Panjaitan ${ }^{1, *}$ Nurfina Aznam ${ }^{2}$ Pujianto $^{3}$ Nedia Erlini ${ }^{1}$ Aza Ayu \\ Din Illahaqi ${ }^{1}$ \\ ${ }^{1}$ Master of Natural Science Education, Faculty of Mathematics and Natural Science, Universitas Negeri \\ Yogyakarta, Indonesia \\ ${ }^{2}$ Departement of Chemistry Education, Faculty of Mathematics and Natural Science, Universitas Negeri \\ Yogyakarta, Indonesia \\ ${ }^{3}$ Master of Physics Education, Faculty of Mathematics and Natural Science, Universitas Negeri Yogyakarta, \\ Indonesia \\ Corresponding Author: muchtarharyanto.2019@student.uny.ac.id
}

\begin{abstract}
This study examines the initial profile of students' understanding of environmental literacy. Descriptive research with a survey method of junior high school students in Central Java which focuses on the initial profile of environmental literacy understanding which includes aspects of understanding environmental literacy, the urgency of environmental literacy in learning and for students, constraint and obstacles and expectations for the future. with a total research sample of 156 students. The results showed that $71.9 \%$ of students considered environmental literacy to be very necessary, which means that the understanding of the importance of environmental literacy is very high but its implementation is still lacking because based on the data there are still some students who have not received environmental literacy learning. The results of this study can be the basis for further research by providing evidence of the importance of improving students' environmental literacy skills to develop their potential and can motivate students to solve problems in the environment.
\end{abstract}

Keywords: Environmental learning, Environmental literacy, Junior high school students

\section{INTRODUCTION}

The environment is an important part of the survival of all living things it needs to be kept in balance. Maintaining environmental balance is the responsibility of all humans. The balance of the environment can be disturbed due to natural occurrences and/or human activities. Disturbances due to natural occurrences cannot be avoided, while disturbances originating from humans can be minimized or even eliminated. One of the ways that can help reduce disturbances in the environmental balance caused by humans is by cultivating an understanding of environmental literacy. According to [1], environmental literacy is a conscious attitude to protect the environment so that its balance is maintained. Realizing what is meant here is not only having knowledge but also having to be responsive and able to provide solutions to environmental problems. Understanding related to environmental literacy should be planted as early as possible in students. Given that students are agents of success and change agents in the community. Research results from [2] state that students' environmental literacy is still low. One of the contributing factors is that the intention to know and study environmental problems is still minimal. Students' environmental literacy is still low due to several factors, namely the lack of student interest in knowing and studying environmental problems and a lack of caring attitude towards the environment. Teachers as educators can be examples and provide stimuli that an understanding of the environment must be the basis of attitudes to be able to solve environmental problems. The importance of instilling environment-based attitudes and skills in learning is still lacking, in the learning process, there are still many teachers who only convey knowledge, not including environment-based attitudes and skills 
[3]. Thus, it is very important to know an overview of the students' environmental insights. This description can be input in developing the design of a lesson to improve environmental literacy.

Knowing the level of environmental literacy and students' attitudes towards the environment can build a sense of love for the environment so that there is a desire to maintain the existence of abundant natural resources in Indonesia. Also, it is hoped that with this environmental literacy students can act wisely towards the environment. The main target of education related to environmental literacy in formal education is to make students have environmental literacy [4]. The use of the term environmental literacy has been used since 1969 by Roth in Amini, which means: The concept of environmental literacy is emphasized by the Environment Education and Training Partnership (EETAP) which states simply that an environmental literate person knows what he will do for the environment, he knows how to do this [5]. A person's environmental literacy status can be measured based on the criteria for the components of environmental literacy, namely: knowledge, cognitive skills, attitude and environmentally responsible behavior [5].

Given the importance of environmental literacy in learning into formal education, it is necessary to increase environmental literacy skills for students. Environmental literacy skills are obtained by the learning process and understanding related to environmental literacy. Learning-related to environmental literacy is intended to develop students' potential, help improve learning outcomes, and can motivate students to solve problems in the environment. Therefore, this study was conducted to determine the profile of junior high school students' environmental literacy understanding.

\section{RESEARCH METHOD}

This research is a descriptive type of research with a survey method. This design was used because this study aims to find out and describe initial environmental literacy understanding of junior high school students in Indonesia. This research was made online in October 2020. An overview of students' environmental literacy can be obtained using various assessment instruments. These instruments can be in the form of questionnaires [6], interviews [7], as well as observation sheets and performance assessments. To map the environmental literacy skills of prospective chemistry teachers can be done using a survey [6]. With this method, it is possible to get information from as many research subjects as possible. The purpose of this study was to determine the initial profile of students' environmental literacy understanding at the junior high school level. Descriptive research describes what it is about things that are natural and by existing facts [8].

The population of this research is junior high school students in Central Java for the 2020/2021 school year. The sampling technique used was a random sampling technique, with total samples 156 students. The instrument determines the initial profile of environmental literacy understanding was obtained from a questionnaire. The questionnaire contains 19 questions covering aspects of 1) understanding environmental literacy, 2) the urgency of environmental literacy in learning and for students 3 ) constraints and obstacles 4) Hope for the future. Quantitative descriptive analysis was conducted to analyze the initial profile of students' environmental literacy understanding.

\section{RESULT AND DISCUSSION}

\subsection{Defining Environment Literacy}

Environmental literacy views the importance of thinking and acting skills that involve mastery of thinking and using scientific thinking in recognizing and addressing environmental problems. Environmental literacy is an important part of developing literacy skills [9]. So from that, environmental literacy is a major part of 21 st-century education [10]. Based on the findings of this study, there are several indicators from each aspect of environmental literacy that are of concern for developing learning plans. Learning with a multidisciplinary approach has the potential to encourage students to use knowledge from theory to practice for making solutions toward environmental problems [11]. Understanding the environmental literacy of junior high school students regarding the understanding of environmental literacy as much as $37.2 \%$ chose environmental literacy as an act of understanding the environment and applying it to community needs. As many as $60.9 \%$ chose environmental literacy as the ability to use environmental literacy knowledge, identify problems and draw conclusions based on evidence. As many as $28.8 \%$ chose environmental literacy as the ability to think critically about environmental problems and cooperate with environmental activists. $56.4 \%$ chose environmental literacy as the capacity to use scientific knowledge, identify questions, and to draw evidencebased conclusions to understand and help make decisions about environmental problems and human interactions with the environment. Environmental 
concern for various environmental problems is a trend today and there are efforts to actively participate in solving problems and actions related to environmental problems by showing attitudinal aspects, namely responses to environmental problems shown through selected lifestyle activities, including purchasing environmentally friendly products, various ways of conserving resources, assistance in environmental regulation [12]. Regulation, using personal and interpersonal means to promote environmentally friendly practices; and support for environmentally friendly policies [13].

Regarding the understanding of environmental literacy is not only limited literally but must be applied in learning to create a clean Indonesia by 2030 . Based on the survey results, $74.4 \%$ of students agreed and $23.1 \%$ of students strongly agreed with the subjects that were followed aimed at developing a literacy skills environment. Meanwhile, $73.1 \%$ of students stated that it was feasible and $12.8 \%$ stated that it was very suitable if the subjects followed were directed to develop their environmental literacy skills. This means that if all these components work together towards the same goal, increasing environmental literacy in students can be maximally achieved. Thus it is expected that the environmental literacy skills of students can increase.

Literacy skills can be improved by using appropriate teaching methods, models, and methods used in learning [14]. Literacy skills can be improved by applying a science learning model that prioritizes the development of attitudes, ideas, and process skills that emphasize the scientific discovery approach [15]. The method used by teachers in developing environmental literacy skills was mostly chosen by students as much as $71.8 \%$, that is through learning activity. Teaching methods are then selected, $32,1 \%$ of the name through the appropriate learning model because the right learning model will affect the results of students' environmental literacy skills. Another way is through learning strategies chosen by $23,1 \%$, and through books and learning media (62.2\%). Learning media in the form of virtual labs can visualize abstract concepts and help students analyze and solve problems using scientific knowledge. So that students 'literacy skills increase [16], and using science literacy textbooks is effective in improving students' literacy skills [17]. And through activities outside learning as much as $39.1 \%$ According to the survey results, students agreed that the method used by the teacher was appropriate for developing environmental literacy skills $(66.7 \%$ appropriate and $11.5 \%$ very suitable). PISA defines three aspects of the following components of scientific competence/process in the assessment of scientific literacy, namely identifying scientific questions, explaining phenomena scientifically and using scientific evidence.

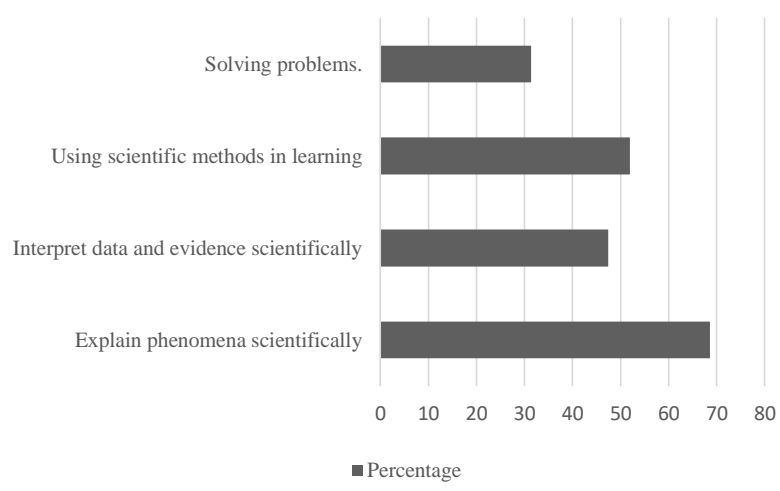

Figure 1 Environmental literacy aspects needed in science learning

The aspect of environmental literacy needed in learning is to explain phenomena scientifically to be the most chosen aspect at $68.6 \%$, explaining scientific phenomena will be easy to do because environmental problems are often found in everyday life [18]. The aspect of interpreting scientific data and evidence was chosen as much as $47.4 \%$, in line with what was stated by [19] the ability to argue with scientific evidence is one indicator that can explain evidence of environmental problems and can brighten the atmosphere of discussion. The aspect of using the scientific method in learning was chosen as much as $51.9 \%$. While the problem-solving aspect was chosen $31.4 \%$, one of the things that students can do is to get used to solving problems on environmental problems so that they are accustomed to being outside the school environment because increasing environmental literacy skills can provide opportunities to improve students' environmental literacy [20].

\subsection{The Urgency of Scientific Literacy in Learning and for Students}

Given the importance of the role of learning which requires students to be able to adapt in the real world, become critical and creative thinkers, problem solvers, and decision-makers. Then a student must have more abilities to achieve educational goals. The purpose of education is to form learning experiences to be able to design problem solutions [21]. Learning is defined as psychic and physical activities in teaching-learning interactions using various learning tools and resources to achieve permanent changes in behavior, both cognitive, affective, and psychomotor [22]. What will then be aspects of the assessment to show the progress 
of student learning. The aspects contained in the concept of competence include: knowledge, understanding, abilities, values, attitudes, and interests [23]. Based on the environmental literacy score of junior high school students in Indonesia, it is still low and there is no significant increase, which is ranked 62 out of 70 countries [24]. Therefore, students must have a good knowledge of environmental literacy. In other words, students must have good environmental literacy for more learning in order to achieve educational goals [25].

Table 1. The percentage table of students related to the reasons for the importance of having environmental literacy for students.

\begin{tabular}{|l|l|}
\hline \multicolumn{1}{|c|}{ Aspects } & Percentage \\
\hline $\begin{array}{l}\text { To increase understanding of } \\
\text { phenomena / disasters due to } \\
\text { environmental damage }\end{array}$ & 67.9 \\
\hline $\begin{array}{l}\text { To improve their abilities students } \\
\text { in evaluating and designing ways to } \\
\text { reduce environmental damage. }\end{array}$ & 60.3 \\
\hline $\begin{array}{l}\text { To improve students' abilities to } \\
\text { interpret data and evidence of } \\
\text { environmental pollution }\end{array}$ & 39.1 \\
\hline $\begin{array}{l}\text { To improve the ability to use } \\
\text { scientific methods in learning }\end{array}$ & 42.9 \\
\hline $\begin{array}{l}\text { To improve students' abilities in } \\
\text { making scientific decisions }\end{array}$ & 28.2 \\
\hline $\begin{array}{l}\text { To improve students' abilities in } \\
\text { solving environmental pollution } \\
\text { problems }\end{array}$ & 37.2 \\
\hline
\end{tabular}

The awareness of the importance of environmental literacy skills for prospective students is very high where $71.9 \%$ of students consider environmental literacy provisions to be very necessary for students. The ability of students' environmental literacy is very influential in learning at school. The survey results showed the need for environmental literacy by students to explain phenomena/disasters due to environmental damage (67.9\%). To evaluate and design ways to reduce environmental problems $(60.3 \%)$. To interpret data and evidence of environmental problems (39.1\%). To use the scientific method in learning $(42.9 \%)$. To make scientific decisions and solve environmental pollution problems (28.2\%). To improve students' abilities in solving environmental pollution problems (37.2\%). If students' environmental literacy is low, it is feared that environmental problems will increase, so that environmental pollution will have an even more impact. Whereas environmental literacy is related to various aspects of life in society, it is related to the activities of people of all ages, both young and old.

Environmental literacy relates to people of all ages, so it needs to be improved to achieve higher literacy [26]. Recognizing the importance of environmental literacy does not mean that everyone has to be an environmental activist, but science allows humans to play a role in making choices that have an impact on the environment and society. Environmental literacy helps shape mindsets, behaviors, and build character to care for the environment and be responsible. Some of the most needed skills for students are analytical skills $(73.1 \%)$, scientific decision making (63.3\%), scientific investigative skills evaluating (56.4\%), while scientific investigative skills evaluating, problem-solving, the ability to interpret the data was chosen less than $50 \%$.

\subsection{Constraints and Obstacles}

As many as $79.5 \%$ of students agree that a lack of understanding of scientific literacy is the main obstacle in implementing it in learning. This means that students must have good environmental literacy skills because the role of students is important in overcoming environmental problems. The problem that is often faced by students in the application of environmental literacy is that they are rarely led to high-order thinking in learning, then coupled with weaknesses in communicating ideas or information straightforwardly, lack of insight in reading literature, and also lack of insight into thinking [27].

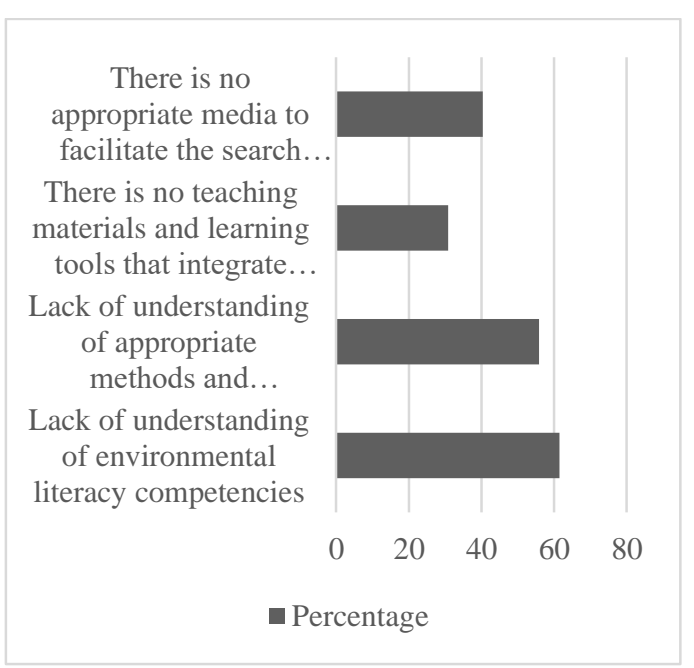

Figure 2 Constraints in integrating environmental literacy skills in learning 
The most perceived obstacles in integrating environmental literacy skills in learning are a lack of understanding of environmental literacy competencies $(61.5 \%)$ and a lack of understanding of appropriate methods and strategies in integrating these competencies $(55.8 \%)$, the absence of teaching materials and tools (40.4\%). Learning that integrates environmental literacy skills, and there is no appropriate media to facilitate the search for environmental literacy skills $(30.8 \%)$.

Regarding the understanding of environmental literacy, several things also become obstacles in learning including difficulties in understanding the phenomena and problems presented in the reading text $(45.5 \%)$, difficulties in identifying problems $(40.4 \%)$, difficulties in communicating environmental problems in presentations $(42.9 \%)$, identifies the problem (45.5\%), communicating learning outcomes in presentations $(42.7 \%)$, interpreting data into tables, graphs, diagrams, etc.; as well as reading tables, graphs, diagrams, etc. (17.9\%), it is difficult to make real decisions/actions on environmental problems (36.5\%). The most difficulties experienced by students were difficulties in understanding the phenomena and problems presented in the reading text and identifies the problem.

Based on these results, it is evident that the understanding of environmental literacy for students needs to be instilled from an early age so that there are no misconceptions in learning activities. Environmental literacy can also be obtained through training, by applying inquiry and scientific thinking processes as well as problem-based learning methods and project-based learning that involve problems that arise in everyday life. Skills training in creating an ecosystem in schools that supports environmental literacy. The skills and creativity to create this ecosystem need trained to develop properly. As many as $46.8 \%$ of students have received material on environmental literacy development, as many as $6.4 \%$ have received training and organization, while $34 \%$ have never received either while studying at school or in the surrounding environment. Environmental literacy is important to master concerning how to understand the environment, health, economy, and other problems faced by modern societies that are highly dependent on science and technology. Thus, students should have a strong understanding of environmental literacy. As many as $69.2 \%$ of students thought that a student should have received strengthening the development of environmental literacy skills since he was in elementary school, while according to $30.1 \%$ of students chose to be in secondary school. This shows that students must first have environmental literacy skills as a provision to overcome existing problems. Environmental literacy learning is not just an understanding of content, specifically the basic concepts of environment, but also a person's ability to understand, communicate (oral and written), and apply knowledge to solve problems so that they have a high attitude and sensitivity to themselves and their environment. Make decisions based on scientific considerations [28].

\subsection{Hope for the Future}

Recognizing the importance of understanding environmental literacy for students, it is supposed to optimize learning in developing environmental literacy, because quality science education will have an impact on the achievement of a country's development [19]. Understanding of science and ability in science will also increase the capacity to hold important and productive jobs in the future. Having environmental literacy is very important, so it is also important to build environmental literacy from an early age, as a generation of educators in the future [29]. Student awareness of the importance of evaluating environmental literacy skills as much as $43.3 \%$ chose to agree and $56.7 \%$ strongly agreed.

The quality of students is inseparable from the preparation process in such a way so that they have deep mastery, besides that it is also expected to have the good environmental literacy skills so that they are better prepared to impact environmental changes so they are not polluted and have environmental literacy insight [30]. Therefore, one of the efforts that must be made is to improve student competencies related to environment literacy. The results of this study can later be used as recommendations for improving environmental literacy skills in students to achieve Indonesia Bersih 2030.

\section{CONCLUSION}

Based on the results of the analysis and discussion, it can be concluded that overall students understand environmental literacy, but they are still lack in implementing environment literacy understanding both inside and outside classroom because there are still some students who have not received environmental literacy learning. The results of this study can be the basis for further research by providing the importance of improving students' environmental literacy to develop their potential, improve learning outcomes and motivate students to solve environmentrelated problems. Therefore, they become the prime pioneer for preparing Indonesia Bersih 2030. 


\section{REFERENCES}

[1] D. Kusumaningrum, Literasi Lingkungan dalam Kurikulum 2013 dan Pembelajaran IPA di SD, Indonesia Journal of Natural Science Education 1 (2018) 57-64. DOI: https://doi.org/10.31002/nse.v1i2.255

[2] M.E. Wolfersberger, D.R. Reutzel, R. Sudweeks, P.C. Fawson, Developing and Validating The Classroom Literacy Environmental Profile (CLEP): A Tool for Examining the "Print Richness" of Early Childhood and Elementary Classrooms, Journal of Literacy Research 36(2) (2004) 211-72. DOI: https://doi.org/10.1207/s15548430j1r3602_4

[3] R. Nasution, Analisis kemampuan literasi lingkungan siswa SMA kelas $\mathrm{X}$ di Samboja dalam pembelajaran biologi, in: Proceeding Biologi Education Conference, vol 13, Universitas Sebelas Maret, Surakarta, 2016, pp. 352-358.

[4] D. Saribas, Investigating the relationship between pre-service teachers' scientific literacy, environmental literacy and life-long learning tendency, in: Proceedings of the Science Education International in International Council of Association for Science Education, vol. 26, Science Education International, 2015, pp. 80100 .

[5] K. Hollweg, J. Taylor, R. Bybee, T. Marcinkowski, W. McBeth, P. Zoido, DC: North American Association for Environmental Education, 2011.

[6] C Joseph, E.O. Nichol, T. Janggu, N. Madi, Environmental Literacy and Attitudes among Malaysian Business Educators, International Journal Sustain High Education, 14 (2013) 196208.

DOI: https://doi.org/10.1108/14676371311312897

[7] I.N.Y. Cheng, W.W.M So, Teachers' Environmental Literacy and Teaching Stories of Three Hong Kong Primary School-Teachers, International Research in Geographical and Environmental Education, 24(1) (2015) 58-79 DOI:

https://doi.org/10.1080/10382046.2014.967111

[8] S. Sudarisman, Analisis kecenderungan metodoe penelitian skripsi mahasiswa di program studi pendidikan biologi, in: Proceedings of the Biology Education Conference, vol.1, Universitas Negeri Sebelas Maret, Surakarta, 2013, pp. 1-7.

[9] R.W. Bybee, Scientific Literacy, Environmental
Issues, and PISA 2006: The 2008 Paul FBrandwein Lecture, Journal of Science Education Technology 17 (2018) 566-585. DOI: https://doi.org/10.1007/s10956-008-9124-4

[10] E.A. Clifford, A Blueprint of Environmental Literacy: Educating Every California in, about, and for the Environment Task Force, California Department of Education, 2015.

[11] R.W. Scholz, C.R. Binder, F. Brand, J. Gallati, D.J. Lang, Q.B Le, R. Seidl, T. Smieszek, M. Stauffacher, Environmental Literacy in Science and Society, Cambridge University Press, 2011. DOI:

https://doi.org/10.1017/CBO9780511921520

[12] E. Gheith, Environmental Literacy among Prospective Classroom Teachers in Jordan, International Journal of Learning, Teaching and Educational Research, 18 (2019) 258-279. DOI: https://doi.org/10.26803/ijlter.18.12.15

[13] B.B. McBride, C.A. Brewer, A.R. Berkowitz, W.T. Borrie, Environmental Literacy, Ecological Literacy, Ecoliteracy: What Do We Mean and How did We Get Here?, Ecosphere, 4 (2013) 7585. DOI: https://doi.org/10.1890/ES13-00075.1

[14] D.D. Utami, Efforts to improve students science literation in science learning, in: Proceedings of the Science Conference, vol. 133, MIPA V Banda Aceh, Aceh, 2018, pp. 133-137.

[15] Y. Yuliati, Penerapan Pembelajaran IPA Berbasis Keterampilan Proses Sains untuk Meningkatkan Literasi Sains pada Mata Pelajaran IPA di Kelas VII Materi Pokok Pencemaran Lingkungan di SMPN 1 Cikijing, Jurnal Cakrawala Pendas 3 (2017) 21-28. DOI: https://doi.org/10.31949/jcp.v3i2.592

[16] I. Ismail, A. Permanasari, W. Setiawan, Efektivitas Virtual Lab Berbasis STEM dalam Meningkatkan Literasi Sains Siswa dengan Perbedaan Gender, Jurnal Inovasi Pendidikan IPA 2 (2016) 190-199. DOI: https://doi.org/10.21831/jipi.v2i2.8570

[17] A. Rusilowati, S.E. Nugroho, S.M. Susilowati, Development of Science Textbook Based On Scientific Literacy For Secondary School, Jurnal Pendidikan Fisika Indonesia 12 (2016) 98-105. DOI: https://doi.org/10.15294/jpfi.v12i2.4252

[18] W.I. Novili, S. Utari, D. Saepuzaman, S. Karim, Penerapan Scientific Approach dalam Upaya Melatihkan Literasi Saintifik dalam Dominan Kompetensi dan Domain Pengetahuan Siswa SMP pada Topik Kalor. Jurnal Penelitian Pembelajaran Fisika 8 (2017) 57-63. DOI: 


\section{https://doi.org/10.26877/jp2f.v8i1.1338}

[19] S. Rahayu, Meningkatkan profesionalisme guru dalam mewujudkan literasi sains siswa melalui pembelajaran kimia/IPA berkonteks isu-isu sosiosaintifik, in: Proceedings of the Science Conference, Universitas Negeri Cendana, NTT, 2016, pp. 1-16.

[20] A. Pahrudin, Irwandani, E. Triyana, Y. Oktarisa, C. Anwar, The Analysis of Pre-Service Physics Teachers in Scientific Literacy: Focus on the Competence and Knowledge Aspects, Jurnal Pendidkan IPA Indonesia 8 (2019) 52-62. DOI: https://doi.org/10.15294/jpii.v8i1.15728

[21] L.W. Anderson, W. Krathwohl Peter, D.R. Airasian, K.A. Cruikshank, R.E. Mayer, P.R. Pintrich, J. Raths, M.C. Wittrock, Taxonomy for_Assessing a Revision, 2001.

[22] S. Sulthon, Pembelajaran IPA yang Efektif dan Menyenangkan bagi Siswa, Elementary Islamic Teacher Journal 4 (2017) 38-54. DOI: https://doi.org/10.21043/elementary.v4i1.1969

[23] D. Cahyani, E. Roviati, Penerapan Pembelajaran IPA Berbasis Keterampilan Proses Sains untuk Meningkatkan Literasi Sains pada Mata Pelajaran IPA di Kelas VII Materi Pokok Pencemaran Lingkungan di SMPN 1 Cikijing, Scientiae Educatia: Jurnal Pendidikan Sains 5 (2016) 122-135. DOI: https://doi.org/10.24235/sc.educatia.v5i2.959

[24] OECD, PISA 2009 Result in Focus, OECD Publishing, 2009.2 DOI: https://doi.org/9789264059603

[25] E. Karademir, U. Ulucinar, Examining the Relationship between Middle School Students' Critical Reading Skills, Science Literacy Skills and Attitudes: A Structural Equation Modeling, Journal of Educational Science and Environment Heal 3 (2016) 29-29 DOI: https://doi.org/10.21891/jeseh.275669

[26] A. Sujana, A. Permanasari, W. Sopandi A M 2, Literasi Kimia Mahasiswa PGSD dan Guru IPA Sekolah Dasar, Journal Pendidikan IPA Indonesia 1 (2014) 91-97.

[27] H. Syofyan, T.L. Amir, Penerapan Literasi Sains dalam Pembelajaran IPA untuk Calon Guru SD, Jurnal Pendidikan Dasar, 4 (2019) 21-31. DOI: https://doi.org/10.21009/JPD.0102.04

[28] S.N. Pratiwi, C. Cari, N.S. Aminah, Pembelajaran IPA Abad 21 dengan Literasi Sains Siswa Aminah, Journal Materi dan Pembelajaran Fisika 9 (2019) 34-42.
[29] G. Angraini, Analisis Kemampuan Literasi Sains Siswa SMA Kelas $X$ di Kota Solok, in: Proceedings of the Mathematics and Science Forum, Universitas Pendidikan Indonesia, Bandung, 2014, pp. 161-70.

[30] E.S. Bahriah, Kajian Sains Calon Guru Kimia pada Aspek Konteks Aplikasi dan Proses Sains Literasi Sains. Edusains 7 (2015) 11-7. DOI: https://doi.org/10.15408/es.v7i1.1395 